\title{
Kualitas dan Kuantitas Produksi Susu Sapi di Kemitraan PT. Greenfields Indonesia Ditinjau dari Ketinggian Tempat
}

\section{Quality and Quantity of Cow Milk Production in PT. Greenfields Indonesia Partnership in Terms of Altitude}

\author{
D. A. Setyorini ${ }^{1}$, S. E. Rochmi ${ }^{1,2}$, T. W. Suprayogi ${ }^{1,2}$, dan M. Lamid ${ }^{2}$ \\ ${ }^{1}$ D3 Paramedik Veteriner, Departemen Kesehatan Fakultas Vokasi, Universitas Airlangga, Surabaya, \\ ${ }^{2}$ Fakultas Kedokteran Hewan Universitas Airlangga, Surabaya \\ Correspondinge-mail: eliana.rochmi@vokasi.unair.ac.id
}

\begin{abstract}
Cow's milk production in Indonesia can't fulfill national cow's milk consumption. As a result, Indonesian milk imports continue to increase. This study aims to observe and examine the effect of altitude on the quality and quantity of cow's milk production The study was conducted at three locations with different heights, consisting of highlands (1065 masl), medium (789 masl), and lowland (499 masl). A total of $10 \mathrm{FH}$ cows from each farm under normal lactation conditions were used in this study. Environmental aspects including temperature and humidity are recorded for 30 days in the morning (07.00 WIB), afternoon (12.00 WIB), and evening (17.00 WIB). The temperature and humidity data of the environment is then converted to a Temperature Humidity Index (THI) value. Based on the THI value, lowland impacts moderate stress, medium and high stress impacts mild heat stress on dairy cows. Milk quality at the three study sites showed no significant difference $(\mathrm{P}>0.05)$. This is because the composition of the feed rations given by the three farms is the same. Milk production at the three study sites were significantly different $(\mathrm{P}<0.05)$. With the highest production in the highland $(14.36$ liter/head/day), medium land (12.10 liter/head/day), and low land (10.48 liter/head/day). It can be concluded that altitude can affect cow milk production in all three farm locations.
\end{abstract}

Key words: altitude, dairy cows, milk production, temperature, THI

\begin{abstract}
ABSTRAK
Produksi susu sapi di Indonesia tidak memenuhi konsumsi susu sapi nasional. Sehingga menyebabkan impor susu Indonesia terus meningkat.Penelitian ini bertujuan untuk mengamati dan mengkaji pengaruh ketinggian tempat terhadap kualitas dan kuantitas produksi susu sapi. Penelitian dilakukan pada tiga lokasi dengan ketinggian berbeda, yaitu dataran tinggi $(1065 \mathrm{mdpl})$, dataran sedang $(789 \mathrm{mdpl})$ dan dataran rendah $(499 \mathrm{mdpl})$. Sebanyak 10 sapi FH dari masing-masing peternakan dalam kondisi laktasi normal digunakan dalam penelitian ini. Aspek lingkungan meliputi suhu dan kelembapan lingkungan dicatat selama 30 hari pada pagi $(07.00 \mathrm{WIB})$, siang (12.00 WIB), dan sore (17.00 WIB). Data suhu dan kelembapan lingkungan kemudian dikonversikan ke nilai index suhu dan kelembapan/Temperature Humidity Index (THI). Berdasarkan nilai THI, dataran rendah memberikan dampak cekaman sedang, sedangkan dataran sedang dan tinggi memberikan dampak cekaman panas ringan pada sapi perah. Kualitas susu di ketiga lokasi penelitian tidak menunjukkan perbedaan yang nyata $(\mathrm{P}>0,05)$. Hal ini disebabkan karena komposisi ransum pakan yang diberikan oleh ketiga peternakan tersebut sama. Produksi susu di ketiga lokasi penelitian berbeda nyata $(\mathrm{P}<0,05)$. Dengan produksi tertinggi di dataran tinggi (14,36 liter/ekor/hari), dataran sedang (12,10 liter/ekor/hari), dan dataran rendah (10,48 liter/ekor/hari). Ketinggian tempat dapat mempengaruhi produksi susu sapi di ketiga lokasi peternakan.
\end{abstract}

Kata kunci :Ketinggian Tempat, Sapi Perah, Susu, Suhu, THI

\section{PENDAHULUAN}

Permintaan susu nasional mengalami peningkatan setiap tahun harus diimbangi dengan peningkatan produksi susu nasional. Susu yang diproduksi didalam negeri sebagian besar berasal dari usaha peternakan sapi perah, dengan demikian sebagai usaha peningkatan produksi susu nasional, populasi dan skala usaha peternakan sapi perah perluditingkatkan (Mariana et al., 2019).

Lingkungan merupakan salah satu faktor penentu tinggi rendahnya tingkat produksi susu pada sapi perah. Cekaman panas yang dapat membuat ternak stress mampu memicu beberapa faktor lain untuk menghambat proses pengeluaran susu. Unsur-unsur lingkungan seperti suhu, kelembapan, dan Temperature 
Humidity Index (THI) merupakan aspek utama yang diukur dalam fisiologi lingkungan dalam bentuk sebagai respon ternak secara langsung(Kartiko et al., 2019).

Jenis ternak sapi perah yang dikembangkan di wilayah penelitian adalah sapi perah Friesian Holstein (FH). Di Indonesia, Sapi FH berasal dari Negara beriklim sedang yang memerlukan suhu optium (sekitar $18^{\circ} \mathrm{C}$ ) dengan kelembapan $55 \%$ untuk menghasilkan produksi yang optimal. Sapi yang ditempatkan pada kondisi lingkungan yang kurang nyaman akan mengalami stres panas dan hal ini dapat berpengaruh terhadap peningkatan konsumsi minum dan penurunan nafsu makan, peningkatan temperatur tubuh, serta perubahan tingkah laku (Heraini et al., 2019).

Sapi perah dapat berkembang baik dan berproduksi optimal pada daerah dengan ketinggian $750 \mathrm{mdpl}$ sampai $1200 \mathrm{mdpl}$. Temperatur lingkungan yang nyaman bagi ternak sapi perah adalah pada suhu antara $13^{\circ} \mathrm{C}$ sampai $18^{\circ} \mathrm{C}$. Sapi perah jenis Friesian Holstein (FH) yang berada di daerah dengan ketinggian tempat $\leq 750$ mdpl akan mempunyai produksi lebih rendah dan produksi susu akan mencapai hasil yang optimal pada daerah pemeliharaan dengan lokasi ketingian $\geq 750$ mdpl (Larasati, 2016).

Peternakan sapi perah kemitraan PT. Greenfields Indonesia terletak diketinggian mencapai 1200 mdpl. Daerah ini termasuk dataran tinggi yang mempunyai kisaran suhu 16$30^{\circ} \mathrm{C}$ dan kelembapan $70-85 \%$. Penilitian ini bertujuan untuk mengetahui pengaruh perbedaan ketinggian lokasi peternakan terhadap kualitas dan kuantitas produksi susu sapi perah di peternakan sapi perah kemitraan PT. Greenfields Indonesia Kabupaten Malang.

\section{MATERI DAN METODE}

Penelitian dilakukan pada peternakan sapi perah kemitraan PT. Greenfields Indonesia. Pengambilan sampel dilakukan di tiga peternakan yang mewakili ketinggian tempatdiantaranya, dataran tinggi (1065 mdpl), dataran sedang (789 mdpl) dan dataran rendah (499 mdpl). Penelitian dilaksanakan pada bulan Maret 2020. Pengujian sampel susu dilakukan di Milk Collcetion Center (MCC) PT. Greenfields Indonesia.

Sapi perah yang digunakan dalam penelitian ini adalah Sapi FH masa laktasi dengan kisaran bulan laktasi 1-3 bulan dan periode laktasi 1-3. Sapi yang digunakan sebanyak 30 ekor dengan rincian peternakan Bapak Yupono Bagyo 10 ekor, peternakan Bapak Wasim 10 ekor dan peternakan Ibu Ida Widyawati 10 ekor. Pengambilan sampel susu dilakukan secara kumulatif dari 10 ekor sapi di setiap peternakan. Ukuran sampel susu sapi yang diambil adalah $250 \mathrm{ml}$.

\section{Pengukuran Ketinggian, Suhu dan Kelembapan}

Pengamatan suhu dan kelembaban udara dilakukan pada pagi (pukul 07.00), siang (pukul 12.00), dan sore hari (pukul 17.00) selama 30 hari. Data suhu dalam derajat celcius $\left({ }^{\circ} \mathrm{C}\right)$ dan kelembaban udara dalam persen (\%). Nilai THI diperoleh dari perbandingan antara suhu $\left({ }^{\circ} \mathrm{C}\right)$ dan kelembapan (\%).

\begin{tabular}{|c|c|c|c|c|c|c|c|c|c|c|c|c|c|c|c|c|c|c|c|c|c|}
\hline & \multicolumn{21}{|c|}{ Kelembaban relatif $(\%)$} \\
\hline${ }^{\circ} \mathrm{C}$ & 0 & 5 & 10 & 15 & 20 & 25 . & 30 & 35 . & 40 & 45 & 50 & 55 & 60 & 65 [ & 70 & 75 & 80 & 85 & 90 & 95 & 100 \\
\hline 23,39 & & & & & & & & & & & & & & 72 & 72 & 73 & 73 & 74 & 74 & 75 & 75 \\
\hline 26,67 & & & & & & & 72 & 72 & 73 & 73 & 74 & 74 & 75 & 76 & 76 & 77 & 78 & 78 & 79 & 79 & 80 \\
\hline 29,44 & & & 72 & 72 & 73 & 74 & 75 & 75 & 76 & 77 & 78 & 78 & 79 & 80 & 81 & 81 & 82 & 83 & 84 & 84 & 85 \\
\hline 32,22 & 72 & 73 & 74 & 75 & 76 & 77 & 78 & 79 & 79 & 80 & 81 & 82 & 83 & 84 & 85 & 86 & 86 & 87 & 88 & 89 & 90 \\
\hline 35,00 & 75 & 76 & 77 & 78 & 79 & 80 & 81 & 82 & 83 & 84 & 85 & 86 & 87 & 88 & 89 & 90 & 91 & 92 & 93 & 94 & 95 \\
\hline 37,78 & 77 & 78 & 79 & 80 & 82 & 83 & 84 & 85 & 86 & 87 & 88 & 90 & 91 & 92 & 93 & 94 & 95 & 97 & 98 & 99 & \\
\hline 40,56 & 79 & 80 & 82 & 83 & 84 & 86 & 87 & 88 & 89 & 91 & 92 & 93 & 95 & 96 & 97 & & & & & & \\
\hline 43,33 & 81 & 83 & 84 & 86 & 87 & 89 & 90 & 91 & 93 & 94 & 96 & 97 & & & & & & Stres & s Rin & ngan & \\
\hline 46,11 & 84 & 85 & 87 & 88 & 90 & 91 & 93 & 95 & 96 & 97 & & & & & & & & Stres & s Sed & dang & \\
\hline 48,89 & 88 & 88 & 89 & 91 & 93 & 94 & 96 & 98 & & & & & & & & & & Stre & es B & Bera & \\
\hline
\end{tabular}

Gambar 1. Nilai Temperature Humidity Index (THI) (Fidler, 1981) 


\section{Pemeriksaan Organoleptik Susu}

Pemeriksaan organoleptik yang dilakukan meliputi, uji warna, uji bau, uji rasa, uji kekentalan dan uji kebersihan. Uji warna dilakukan dengan menggunakan susu sebanyak 5 $\mathrm{ml}$ yang dimasukkan ke dalam tabung reaksi, kemudian warna susu diperiksa menggunakan latar belakang kertas putih. Uji bau dilakukan dengan menuangkan susu sebanyak $5 \mathrm{ml}$ ke dalam tabung reaksi kemudian dicium baunya. Uji rasa dilakukan dengan menuangkan sejumlah kecil susu di telapak tangan kemudian dicicipi. Uji kekentalan dilakukan dengan menggunakan 5 $\mathrm{ml}$ susu yang dituangkan ke dalam tabung reaksi sebanyak $5 \mathrm{ml}$ kemudian digoyangkan perlahan. Uji kebersihan dilakukan dengan cara susu disaring menggunakan kain saring sebelum masuk ke alat pendingin (cooling), kotoran yang terdapat dalam susu akan tersangkut pada kain saringan.

\section{Uji Alkohol}

Uji alkohol dilakukan menggunakan milk alcohol gun tester yang sudah diisi dengan alkohol 70\%. Ujung pistol alkohol dicelupkan kedalam susu hingga lubang tercelup seluruhnya, kemudian pistol alkohol diangkat dan dibalik hingga pada tabung kaca keluar sampel susu dan cairan alkohol $70 \%$ dengan perbandingan volume yaitu 1:1, pistol alkohol digoyang-goyang kemudian dilakukan pengamatan pada dinding tabung milk alcohol gun test (Sutrisna et al., 2014).

\section{Pemeriksaan Berat Jenis}

Pemeriksaan berat jenis pada sampel susu menggunakan laktodensimeter. Sebelum dilakukan pemeriksaan berat jenis, sampel susu diaduk terlebih dahulu. Kemudian sampel susu di tuangkan ke dalam tabung reaksi melalui dinding tabung tanpa menimbulkan buih. Kemudian laktodensimeter dicelupkan ke dalam tabung yang berisi susu sehingga turun naik. Pembacaan skala yang tertera di laktodensimeter. Angka yang tertera menunjukkan angka ke 2 dan ke 3

$\mathrm{BJ}=\mathrm{SKALA}+(27,5-\mathrm{T}) \times 0,0002$

Keterangan: $\mathrm{T}=\mathrm{Suhu}$ susu

dibelakang koma, Apabila angka yang terterapada laktodensimeter 28 maka hasil yang didapat adalah 1,028. Besar koefisien pemuaian susu adalah 0,0002 setiap derajat celcius serta digunakan laktodensimeter yang ditera pada suhu $27,5^{\circ} \mathrm{C}$. Perhitungan berat jenis susu yaitu suhu laktodensimeter yang ditera dikurangi dengan suhu susu, kemudian ditambah dengan skala laktodensimeter yang didapat dan dikalikan dengan koefisien pemuaian susu. Perhitungan berat jenis susu sesuai dengan rumus berikut.

\section{Uji Kualitas Susu}

Kualitas susu diukur menggunakan Lactoscanmerk Milkotronic dan dibuat oleh Milkotronic Ltd. Lactoscan Bulgaria, dengan cara kerja yaitu lactoscan dibersihkan terlebih dahulumenggunakan aquades melalui ujung jarum atau saluran inlet bagian dari alat lactoscan, kemudian sampel susudiaduk menggunakan sendok pengaduk agar sampel susu homogen, lalu sampel susu ditakar menggunakan backer glass sebanyal $25 \mathrm{~mL}$. selanjutnya sampel susu dimasukkan ke dalam tabung, lalu masukan tabung ke saluran inlet bagian dari alat lactoscan. Tombol OK pada alat tersebut ditekan sehingga sampel akan tersedot masuk ke dalam alat. Tombol OK ditekan kembali untuk memulai proses analisis susu. Data hasil analisis dapat dibaca pada layar lactoscan diantaranya kadarProtein, Lemak (Fat), Solid Non Fat (SNF), dan Total Solid (TS). Apabila pengujian sampel susu selesai, alatlactoscan dibersihkan dengan aquades (Nugraha et al., 2016).

\section{Uji Resazurin}

Uji resazurin dilakukan dengan memasukkan sampel susu segar sebanyak $10 \mathrm{ml}$ ke dalam tabung reaksi lalu ditambah dengan 1 $\mathrm{ml}$ reagen resazurin, kemudian menggunakan waterbath sampel susu dipanaskan pada suhu 36 ${ }^{\circ} \mathrm{C}$ selama 30 menit. Dilakukan pengamatan terhadap perubahan warna yang terjadi pada masing-masing sampel susu (Mariyani et al., 2012).

Tabel 1. Mutu susu berdasarkan warna hasil

\begin{tabular}{|c|c|}
\hline Warna & Mutu \\
\hline Biru & Excellent \\
\hline Biru-biru kemerahan & Good \\
\hline $\begin{array}{l}\text { Biru kemerahan- } \\
\text { merah muda }\end{array}$ & Fair (sedang) \\
\hline $\begin{array}{l}\text { Merah muda-ke putih- } \\
\text { putihan }\end{array}$ & Poor/ jelek \\
\hline Putih & $\begin{array}{l}\text { Bad / sangat } \\
\text { jelek }\end{array}$ \\
\hline
\end{tabular}

Sumber : Mariyani et al. (2012). 


\section{Produksi Susu}

Produksi susu sapi perah diamati dari catatan produksi susu dari 10 ekor sapi Friesian Holstein di masing-masing tiga peternakan sapi perah kemitraan PT. Greenfields Indonesia yang sudah ditentukan selama satu bulan pada bulan Maret 2020. Dari catatan produksi tersebut, kemudian dihitung untuk mengetahui rata-rata produksi per ekor sapi per hari.

\section{Analisis Data}

Data suhu, kelembapan lingkungan, kualitas dan kuantitas susu yang diperoleh dianalisis ragam menggunakan (ANOVA atau Analysis of variance) pada taraf 5\% $(0,05)$ untuk mengetahui perbedaan antara ketinggian terhadap kualitas dan kuantitas susu sapi. Apabila hasil $\mathrm{P}$ Value $<0,05 \quad(\mathrm{P}<0,05)$ menunjukkan terdapat pengaruh ketinggian tempat terhadap kualitas dan kuantitas susu sapi. Dilanjutkan dengan Uji Beda Nyata Terkecil (BNT) untuk mengetahui perbedaan antar ketinggian. Data yang didapat dianalisis dibantu menggunakan IBM SPSS Statistics 20.

\section{HASIL DAN PEMBAHASAN}

\section{Kondisi Lingkungan}

Data dari hasil analisis ragam menunjukkan perbedaan ketinggian tempat berpengaruh $\quad(\mathrm{P}<0,05) \quad$ terhadap kondisi lingkungan yaitu, suhu udara dan kelembaban. Hasil pengamatan diperoleh data lokasi dataran tinggi, dataran sedang dan dataran rendah menunjukkan terdapat perbedaan suhu dan kelembapan.

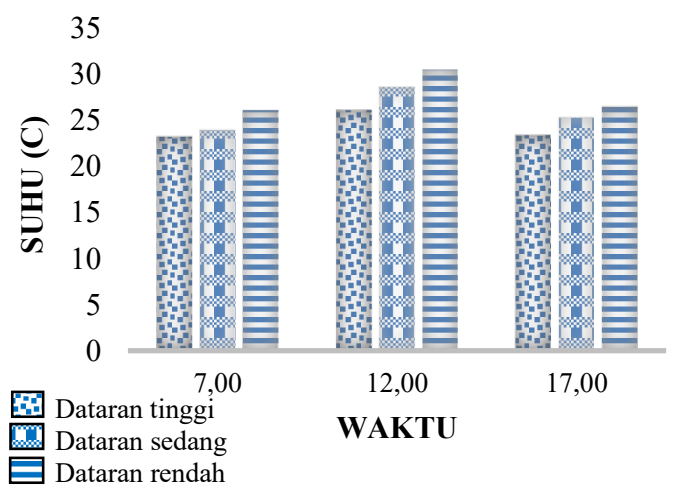

Gambar 2. Suhu dan kelembapan lokasi penelitian
Hasil pengamatan di lokasi dataran tinggi menunjukkan bahwa nilai THI di dataran tinggi yaitu 72-77 dengan kisaran suhu lingkungan $23,2-26,1^{\circ} \mathrm{C}$ dan kelembapan udara berkisar antara 78,75-85,75\%. Berdasarkan nilai THI yang diperoleh dapat dikategorikan sapi perah di lokasi dataran tinggi mengalami cekaman ringan.

Hasil pengamatan di lokasi dataran sedang menunjukkan bahwa nilai THI di dataran sedang yaitu 74-78 dengan kisaran suhu lingkungan $23,6-26,9{ }^{\circ} \mathrm{C}$ dan kelembapan udara berkisar antara $64-85 \%$. Berdasarkan nilai THI yang diperoleh dapat dikategorikan sapi perah di lokasi dataran tinggi mengalami cekaman ringan.

Hasil pengamatan di lokasi dataran rendah menunjukkan bahwa nilai THI di dataran tinggi yaitu 77-79 dengan kisaran suhu lingkungan $26,1-30,5{ }^{\circ} \mathrm{C}$ dan kelembapan udara berkisar antara $60-81,5 \%$. Berdasarkan nilai THI yang diperoleh dapat dikategorikan sapi perah di lokasi dataran tinggi mengalami cekaman sedang.

Tabel 2. Kondisi lingkungan

\begin{tabular}{|c|c|c|c|}
\hline No. & $\begin{array}{c}\text { Lokasi } \\
\text { peternakan }\end{array}$ & $\begin{array}{c}\text { Ketinggian } \\
\text { tempat }\end{array}$ & Keterangan \\
\hline 1. & $\begin{array}{l}\text { Dusun } \\
\text { Kampung } \\
\text { Baru }\end{array}$ & 1065 mdpl & $\begin{array}{l}\text { Dataran } \\
\text { tinggi }\end{array}$ \\
\hline 2. & $\begin{array}{l}\text { Dusun } \\
\text { Jambuwer }\end{array}$ & 789 mdpl & $\begin{array}{l}\text { Dataran } \\
\text { sedang }\end{array}$ \\
\hline 3. & $\begin{array}{l}\text { Dusun } \\
\text { Kenongo }\end{array}$ & 449 mdpl & $\begin{array}{l}\text { Dataran } \\
\text { rendah }\end{array}$ \\
\hline
\end{tabular}

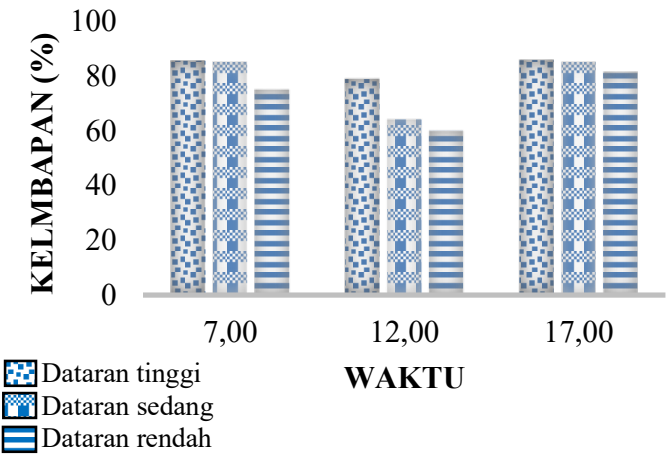


Tabel 3. Uji organoleptik

\begin{tabular}{ccccc}
\hline Ketinggian tempat & \multicolumn{4}{c}{ Uji organoleptik } \\
\cline { 2 - 5 } & Warna & Bau & Rasa & Kekentalan \\
\hline Dataran tinggi (1065 mdpl) & Putih & Khas susu sapi & Khas susu sapi & Normal \\
\hline Dataran sedang (789 mdpl) & Putih & Khas susu sapi & Khas susu sapi & Normal \\
Dataran rendah (499 mdpl) & Putih & Khas susu sapi & Khas susu sapi & Normal \\
\hline
\end{tabular}

\section{Uji Organoleptik}

Hasil uji organoleptik secara keseluruhan tidak ada yang menyimpang dari standar normal susu sapi. Pada uji warna ketiga sampel menunjukkan hasil yang normal yaitu putih.Uji bau dari ketiga sampel susu sapi menunjukkan tidak terdapat penyimpangan yaitu memiliki bau khas susu sapi. Uji rasa dari ketiga sampel susu sapi menunjukkan hasil yang normal yaitu sampel susu memiliki rasa khas susu sapi yaitu rasa sedikit manis dan sedikit asin.Hasil uji kekentalan dari ketiga sampel seluruhnya adalah normal. Dari hasil uji organoleptik tersebut maka susu sapi dari ketiga peternakan tersebut dapat dikatakan baik, karena tidak ada penyimpangan terhadap warna, bau, rasa, dan kekentalan.

\section{Uji Alkohol}

Hasil analisis data uji alkohol sampel susu menunjukkan reaksi negatif. Reaksi negatif ditandai dengan tidak terjadi reaksi koagulasi pada sampel susu. Hal ini menunjukkan bahwa ketiga sampel susu sapi memiliki kualitas yang baik dan layak dikonsumsi. Uji alkohol negatif menunjukkan sampel susu masih segar dan tidak ada produksi asam laktat oleh bakteri yang menyebabkan susu menjadi asam.

\section{Pemeriksaan Berat Jenis}

Penetapan berat jenis susu sapi menggunakan laktodensimeter. Pengukuran berat jenis sampel susu sapi dilakukan dalam sehari dua kali yaitu pada pagi dan sore hari. Standar nilai berat jenis susu berdasarkan ketentuan di
Milk Collection Center (MCC) adalah pada pagi hari berat jenis sampel susu sapi minimal 1,024 dan sore hari minimal 1,022.

Tabel 4. Pemeriksaan berat jenis sampel susu

\begin{tabular}{clcc}
\hline \multirow{2}{*}{ No. } & \multicolumn{2}{c}{$\begin{array}{c}\text { Ketinggian } \\
\text { Tempat }\end{array}$} & \multicolumn{2}{c}{ Berat jenis $(\mathrm{g} / \mathrm{ml})$} \\
\cline { 3 - 4 } 1. & $\begin{array}{l}\text { Dataran tinggi } \\
(1065 \text { mdpl })\end{array}$ & 1,025 & Sore \\
2. & $\begin{array}{l}\text { Dataran sedang } \\
\text { (789 mdpl) }\end{array}$ & 1,025 & 1,024 \\
3. & $\begin{array}{l}\text { Dataran rendah } \\
(499 \text { mdpl) }\end{array}$ & 1,024 & 1,022 \\
\hline
\end{tabular}

\section{Uji Resazurin}

Hasil percobaan yang didapat bahwa sampel susu sapi Bapak Yupono Bagyo dan Bapak Wasim tidak mengalami perubahan warna dan tidak terdapat mikroba yang berkembang pada sampel tersebut. Berdasarkan kriteria penilaian mutu dan warnanya adalah susu tersebut termasuk susu yang memiliki mutu dan kualitas yang excellent karena tidak terdapat bakteri yang mereduksi reagen resazurin. Sedangkan sampel susu sapi dari peternakan Ibu Ida Widyawati mengalami perubuhan warna yaitu dari warna biru menjadi biru kemerahan. Berdasarkan kriteria penilaian mutu dan kualitas adalah susu tersebut tergolong susu yang memiliki mutu dan kualitas yang bagus (good) karena hanya sedikit bakteri yang mereduksi warna reagen resazurin.

Tabel 5. Data uji resazurin

\begin{tabular}{ccccc}
\hline No. & Ketinggian tempat & $\begin{array}{c}\text { Uji } \\
\text { resazurin }\end{array}$ & Warna & Mutu \\
\hline 1. & Dataran tinggi $(1065 \mathrm{mdpl})$ & 3 & Biru & Excellent \\
2. & Dataran sedang $(789 \mathrm{mdpl})$ & 3 & Biru & Excellent \\
3. & Dataran rendah $(499 \mathrm{mdpl})$ & 4 & Biru-biru kemerahan & Good \\
\hline
\end{tabular}




\section{Uji Kualitas Susu}

Berdasarkan hasil analisis ragam kandungan lemak susu (Fat) tidak terdapat perbedaan nyata $(\mathrm{P}>0,05)$ pada ketiga tempat penelitian. Tidak adanya perbedaan pada ketiga tempat ini dikarenakan susunan pakan yang diberikan pada ketiga lokasi adalah sama, sehingga penyusun sintesis lemak susu seperti jumlah konsumsi serat kasar pada pakan yang merupakan bahan pembentuk asam asetat dan butirat tidak berbeda nyata.

Berdasarkan hasil Analisis ragam kandungan SNF (Solid Not Fat) pada ketiga lokasi tersebut tidak terdapat perbedaan yang nyata $(\mathrm{P}>0,05)$. SNF adalah padatan tanpa lemak yang terkandung dalam susu. Tidak terdapat perbedaan nyata pada ketiga lokasi ini dikarenakan kandungan lemak susu pada ketiga dataran juga tidak ada perbedaan, sehingga tidak mempengaruhi kandungan SNF pada ketiga dataran ini.

Berdasarkan hasil analisis ragam Total Solid (TS) susu pada ketiga lokasi tersebut tidak terdapat perbedaan yang nyata $(\mathrm{P}>0,05)$. Total solid adalah jumlah total padatan yang terdapat dalam susuyaitu protein, lemak, dan laktosa. Tidak adanya perbedaan nyata pada ketiga lokasi ini dikarenakan komposisi susu pada ketiga lokasi ini tidak mengalami perbedaan yang nyata.

Berdasarkan hasil analisis ragam Kandungan protein susu pada ketiga lokasi tersebut tidak terdapat perbedaan yang nyata $(\mathrm{P}>0,05)$. Kandungan protein susuberasal dari protein pakan, meskipun pada konsumsi protein pakan terdapat perbedaan nyata, namun tidak mempengaruhi kandungan protein susu. Hal ini dikarenakan kandungan protein susu lebih sulit dimodifikasi dan cenderung terkait dengan faktor genetis.

\section{Produksi Susu}

Hasil analisis ragam menunjukkan rataan suhu, kelembaban, dan THI di ketiga lokasi penelitian menunjukkan perbedaan nyata, sehingga berpengaruh pada produksi susu. Hasil dari analisis Uji Beda Nyata Terkecil (BNT) menunjukkan produksi susu di ketinggian tempat 499 mdpl (dataran rendah) berbeda nyata dengan ketinggian tempat 789 mdpl (dataran sedang) dan ketinggian tempat $1065 \mathrm{mdpl}$ (dataran tinggi), tetapi produksi susu di ketinggian tempat 789 mdpl (dataran sedang) tidak berbeda nyata dengan ketinggian tempat 1065 mdpl (dataran tinggi). Ditinjau dari hasil uji Uji Beda Nyata Terkecil (BNT) produksi susu tertinggi berada di ketinggian tempat 799 mdpl (dataran sedang), tetapi hasil produksi susu nya tidak berbeda nyata dengan produksi susu si ketinggian tempat 1065 mdpl (dataran tinggi).

Hasil penelitian ini menunjukkan bahwa kondisi lingkungan yang ideal dengan produksi susu tinggi adalah pada ketinggian $1065 \mathrm{mdpl}$ dan 789 mdpl. Setiap kenaikan ketinggian, terjadi penurunan suhu dan kelembapan udara serta peningkatan produksi susu. Hal ini disebabkan karena ternak membutuhkan suhu lingkungan dan kelembapan udara yang optimal untuk kehidupan dan bereproduksi. Sapi perah akan berproduksi optimal pada suhu $18^{\circ} \mathrm{C}$ dengan kelembapan $55 \%$ (Berman, 2005). Suhu dan kelembapan udara yang berada di luar zona nyaman mengakibatkan terjadinya cekaman (Gantner et al., 2017). Kondisi cekaman tertinggi yang terjadi pada dataran rendah mempengaruhi produktivitas secara nyata. Sapi perah didataran rendah memiliki produktivitas yang lebih rendah jika

Tabel 6. Uji kualitas susu

\begin{tabular}{cccccc}
\hline No. & Ketinggian tempat & Fat & SNF & TS & Protein \\
\hline 1. & Dataran tinggi $(1065 \mathrm{mdpl})$ & 3.80 & 8.66 & 12.46 & 2.93 \\
2. & Dataran sedang $(769 \mathrm{mdpl})$ & 3.98 & 8.51 & 12.49 & 2.91 \\
3. & Dataran rendah $(499 \mathrm{mdpl})$ & 4.00 & 8.32 & 12.32 & 2.73 \\
\hline
\end{tabular}

Tabel 7. Produksi susu

\begin{tabular}{ccc}
\hline No. & Ketinggian tempat & $\begin{array}{c}\text { Produksi susu sapi } \\
\text { (liter/ekor/hari) }\end{array}$ \\
\hline 1. & Dataran tinggi $(1065 \mathrm{mdpl})$ & 13,36 \\
2. & Dataran sedang $(789 \mathrm{mdpl})$ & 14,10 \\
3. & Dataran rendah $(499 \mathrm{mdpl})$ & 10,48 \\
\hline
\end{tabular}


dibandingkan dengan sapi perah didataran sedang meskipun dari aspek pemeliharaan dan pemberian pakan kedua lokasi tersebut tidak berbeda.

Hal ini menunjukkan bahwa pengaruh cekaman yang disebabkan oleh kondisi lingkungan sangat berpengaruh pada produksi susu sapi. Produksi susu yang rendah pada ternak di dataran rendah menggambarkan usaha adaptasi ternak terhadap cekaman kondisi lingkungan. Hal ini disebabkan karena produksi susu yang tinggi menyebabkan peningkatan sensitivitas terhadap cekaman panas. Sapi perah dengan produksi susu 18,5 kg/hari memproduksi panas 27,3\% lebih tinggi jika dibandingkan produksi panas pada sapi non laktasi. Sapi perah laktasi dengan produksi $31.6 \%$ memproduksi panas $48,5 \%$ lebih tinggi (Purwanto et al., 1990). Ambang batas toleransi panas turun sebesar $5^{\circ} \mathrm{C}$ setiap peningkatan produksi susu $10 \mathrm{~kg} / \mathrm{hari}$ (Berman, 2005).

Ternak sapi perah pada tempat dengan ketinggian tempat $489 \mathrm{mdpl}$ mengalami cekaman sedang yang mengakibatkan perubahan fisiologis dan berpengaruh terhadap produksi susu dibandingkan dengan ternak sapi perah pada ketinggian tempat $799 \mathrm{mdpl}$ dan $1065 \mathrm{mdpl}$. Perubahan fisiologis pada sapi FH akibat stres panas adalah penurunan nafsu makan dan peningkatan konsumsi minum, peningkatan katabolisme dan penurunan metabolisme, peningkatan pelepasan panas melalui penguapan, penurunan konsentrasi hormon dalam darah, peningkatan respirasi, temperature tubuh, dan denyut jantung (McDowell, 1972).

Sapi FH bereaksi terhadap perubahan suhu dapat dilihat dari respon denyut jantung dan pernapasan merupakan mekanisme dari tubuh sapi untuk melepaskan atau mengurangi panas yang diterima dari luar tubuh ternak. Tubuh ternak akan menyebarkan panas yang diterima ke dalam organ-organ yang lebih dingin melalui peningkatan denyut jantung. Tubuh ternak akan membuang atau mengganti panas dengan udara disekitarnya melalui peningkatan frekuensi pernapasan. Peningkatan konsumsi air, penurunan produksi susu, peningkatan volume urin, dan penurunan konsumsi pakan akan terjadi apabila cekaman panas terus berlangsung (Yani and Purwanto, 2006). Perubahan hormonal juga terjadi pada ternak yang terpapar suhu tinggi. Penurunan aktivitas thyroid mencerminkan ternak yang mengalami kesulitas untuk beradaptasi dengan lingkungannya, sedangkan peningkatan cortisol mencerminkan ternak mengalami cekaman panas. Konsentrasi somatotropin susu menurun signifikan ketika nilai THI melebihi 70 yang menyebabkan produksi susu menurun (Sutedjo, 2016).

\section{KESIMPULAN}

Perbedaan ketinggian tempat lokasi peternakan memberikan perbedaan yang nyata terhadap suhu dan kelembapan lingkungan. Kondisi lingkungan pada dataran rendah memberikan dampak cekaman sedang, dataran tinggi dan dataran sedang memberikan dampak cekaman panas ringan pada sapi perah. Perbedaan ketinggian tempat memberikan pengaruh nyata terhadap kuantitas produksi susu di ketiga lokasi penelitian namun tidak memberikan pengaruh terhadap kualitas susu. Ditinjau dari kuantitas susu sapi yang dihasilkan ketinggian tempat 799 mdpl memiliki produksi susu tertinggi namun perbedaan nya tidak signifikan dengan kuantitas produksi susu di ketinggian tempat $789 \mathrm{mdpl}$. Kuantitas produksi susu terendah berada di ketinggian 499 mdpl.

\section{DAFTAR PUSTAKA}

Kartiko, M. A., P. Sambodho, dan D. W. Harjanti. 2019. Respon fisiologis sapi laktasi akibat modifikasi lingkungan kandang. Agromedia 37 (2): 76-82

Berman, A. 2005. Estimates of heat stress relief needs for holstein dairy cows. Journal of Animal Science. 83(6): 1377-1384.

Fidler, A.P. 1981. Heat Stress in Dairy Cattle. Agriculture and Natural Resources. Available at: https://www.uaex.edu/publications/pdf/fsa3040.pdf.

Gantner, V., T. Bobić, M. Gregić, R. Gantner, K. Kuterovac, and K. Potočnik. 2017. Differences in Resistance to Heat Stress Depending on the Breed of Dairy Cattle. Journal Dairy 67(2): 112-122.

Heraini, D., dan B. P. Purwanto, Suryahadi. 2019. Perbandingan Suhu Lingkungan dan Pengaruh Pakan terhadap Produktivitas Sapi Perah di Daerah dengan Ketinggian Berbeda. Jurnal Ilmiah Peternakan Terpadu $\quad 7(2)$ : 234-240. 
Larasati, D.A. 2016. Faktor yang Berpengaruh terhadap Produktivitas Susu Sapi Perah di Desa Geger Kecamatan Sendang Kabupaten Tulungagung. Jurnal Geografi 14 (1): 34-41.

Mariana, E., C. Sumantri, D. A. Astuti, dan A. Anggraeni. 2019. Mikroklimat, Termoregulasi dan Produktivitas Sapi Perah Friesians Holstein pada Ketinggian Tempat Berbeda. Jurnal Ilmu Teknologi dan Peternakan Tropis 6(1): 70-77.

Mariyani, N. 2012. Laporan Analisis Mutu Mikrobiologi Pangan. Program Keahlian Supervisor Jaminan Mutu Pangan Sutrisna, D.Y., I. K. Suada, dan I. P. Sampurna. Direktorat Program Diploma Institut Pertanian Bogor.

McDowell, R.E., 1972. Improvement of Livestock Production in Warm Climates. Editor W.H. Freeman and Co. San Fransisco. Journal Natural Science 5 (1A): 1-128.

Nugraha, B.K., L. B. Salman, dan E. Hernawan. 2016. Kajian Kadar Lemak, Protein dan Bahan Kering Tanpa Lemak Susu Sapi Perah Fries Holland pada Pemerahan Pagi dan Sore di KPSBU Lembang. Jurnal Universitas Padjajaran.

Purwanto, B.P., Y. Abo, R. Sakamoto, F. Furumoto, dan S. Yamamoto. 1990. Diurnal Patterns of Heat Production and Heart Rate Under Thermoneutral Conditions in Holstein Friesian Cows Differing in Milk Production. Journal of Agricultural Science 114 (2): 139-142.

Sutedjo, H. 2016. Dampak Fisiologis dari Cekaman Panas pada Ternak. Jurnal Nukleus Peternakan 3(1): 93-105.

2014. Kualitas susu kambing selama penyimpanan pada suhu ruang berdasarkan berat jenis, uji didih, dan kekentalan. Jurnal Indonesia Medicus Veterinus 3 (1) : 60-67

Yani, A., dan B. P. Purwanto. 2006. Pengaruh Iklim Mikro terhadap Respons Fisiologis Sapi Peranakan Fries Holland dan Modifikasi Lingkungan untuk Meningkatkan Produktivitasnya (ULASAN). Media Peternakan 29: 35-46. 